\title{
EFEKTIVITAS PENYAMPAIAN SPT TAHUNAN WP OP MELALUI e-FILLING TERHADAP TARGET PENERIMAAN SPT TAHUNAN PADA KANTOR PELAYANAN PAJAK PRATAMA MATARAM TIMUR
}

\author{
Abdul Manan \\ Fakultas Ekonomi dan Bisnis Universitas Mataram \\ abdmanan@unram.ac.id \\ Rahayu Ningsih \\ Program Studi D-III Perpajakan Fakultas Ekonomi dan Bisnis \\ Universitas Mataram
}

\begin{abstract}
ABSTRAK
Peranan pajak sangat penting dalam melaksanakan pembangunan dan meningkatkan kesejahteraan bagi seluruh rakyat Indonesia.Denyut nadi pembangunan di Indonesia bersumber dari APBN yang sebagian besar di topang dari penerimaan melalui sektor Perpajakan.Berdasarkan data APBN tahun 2018, pendapatan negara mencapai $1.894,7$ triliun, dari jumlah tersebut sebesar $75 \%$ bersumber dari penerimaan perpajakan (DJP.Nusra,2018).Untuk meningkatkan penerimaan pajak, pemerintah mengeluarkan salah satu kebijakan pelaporan dan penyampaian Surat Pemberitahuan (SPT) dengan system e-filin, yaitu suatu cara penyampaian SPTsecara elektronik yang dilakukan secara online dan real time.Sistem e-filling ini diharapkan membantu memangkas biaya dan waktu yang dibutuhkan wajib pajak untuk mempersiapkan,memproses, dan melaporkan SPT ke kantor pelayanan Pajak secara benar dan tepat waktu (Anonim, 2018)

Praktek Kerja Lapangan (PKL) ini bertujuan untuk 1) mengetahui target dan realisasi Penyampaian SPT Tahunan dengan adanya e-Filling pada Kantor Pajak Pratama Mataram Timur, dan 2) mengetahui efektivitas penyampaian SPT Tahunan melalui $e$ Filling di Kantor Pelayanan Pajak Pratama Mataram Timur. Hasil PKL menunjukkan bahwa, 1) Secara umum target dan realisasi penerimaan SPT Tahunan terus meningkat dalam 3 tahun terkhir namun capaianya menunjukkan ada penurunan dari tahun 2017 ke 2018 yaitu dari 113,87 menjadi 99,60\% sedangkan tahun 2018 ke 2019 capaiannya meningkat menjadi 105,10\%. 2) selama tiga tahun terakhir (2017, 2018 dan 2019) penyampaian SPT Tahunan melalui e-Fillingsebagai berikut: a) pada tahun 2017 dinyatakan sangat efektif dengan persentase penerimaan SPT Tahunan WP OP tahun 2017 sebesar 113,88 \%; b) Pada tahun 2018 penyampaian SPT Tahunan melalui e-Filling sebesar $99.60 \%$, dengan katagori efektif; c) tahun 2019 penyampaian SPT Tahunan WP OP melalui e-Filling mengalami peningkatan menjadi $105.10 \%$ atau termasuk dalam kriteria sangat efektif.
\end{abstract}

Kata kunci: Efektivitas, system e-filing 


\section{ABSTRACT}

The role of taxes is very important in carrying out development and improving the welfare of all Indonesian people. The development pulse in Indonesia is sourced from the state budget, which is largely supported by revenue through the taxation sector. Based on the 2018 State Budget data, state revenues reached 1,894.7 trillion, of which $75 \%$ came from tax revenue (DGT, Nusra, 2018). To increase tax revenue, the government issued a policy of reporting and submitting Notification Letter (SPT) with the e-filing system, which is a way of electronically delivering SPT which is done online and in real time. This e-filling system is expected to help cut costs and time needed by taxpayers to prepare, process, and report tax returns to the tax office correctly and on time (Anonymous, 2018).

This Field Work Practice (PKL) aims to 1) find out the targets and realization of the Annual Submission of SPT with e-Filling at the East Mataram Pratama Tax Office, and 2) to know the effectiveness of the submission of the Annual SPT through e-Filling at the East Mataram Pratama Tax Service Office. The results of street vendors show that, 1) In general, the target and realization of Annual SPT receipts continue to increase in the last 3 years but the achievements indicate a decline from 2017 to 2018, from 113.87 to $99.60 \%$ while in 2018 to 2019 the achievements have increased to $10510 \%$. 2) during the last three years (2017, 2018 and 2019) the submission of the Annual SPT via e-Filling as follows: a) in 2017 was declared very effective with the percentage of receipt of the Annual WP WP Annual Tax in 2017 amounting to $113.88 \%$; b) In 2018 the submission of Annual SPT through e-Filling was 99.60\%, with an effective category; c) in 2019 submission of Annual Annual Tax Return by e-Filling increased to $105.10 \%$ or included in the highly effective criteria.

\section{Keywords: Effectiveness, e-filing system}

\section{PENDAHULUAN}

Peranan pajak sangat penting dalam melaksanakan pembangunan dan meningkatkan kesejahteraan bagi seluruh rakyat Indonesia. Denyut nadi pembangunan di Indonesia bersumber dari APBN yang sebagian besar di topang dari penerimaan melalui sektor Perpajakan.Berdasarkan data APBN tahun 2018, Pendapatan negara tahun 2018 mencapai 1.894,7 triliun, dimsns 75\% merupakan pendapatan yang bersumber dari pajak. Angka tersebut di dapat melalui:

a. Kepabeanan \& Cukai: Rp194,1 triliun.

b. Penerimaan pajak: Rp1.414 triliun:

1) Pph Migas: Rp38,1 triliun

2) Pajak non Migas: Rp1.385,9 triliun (Kanwil DJP, NUSRA, 2018).

Semakin tingginya peranan pajak dalam mendanai APBN tidak terlepas dari upaya pemerintah untuk terus memperbaiki kinerja perpajakan, melalui kebijakan, 
strategi perpajakan, dan implementasi reformasi pajak yang berkelanjutan, serta di dukung oleh peningkatan kepatuhan wajib pajak.Besar atau kecilnya pajak yang diterima oleh suatu negara sangat berpengaruh terhadap jalannya pembangunan negara tersebut. Semakin besar jumlah angka pajak yang di terima oleh negara, maka kesempatan untuk membangun ataupun membenahi pembangunan di setiap daerah yang akan terealisasi, sehingga dampaknya dapat dirasakan oleh setiap kalangan masyarakat.

Untuk mensuskeskan pembangunan nasional, pajak kedudukan yang strategis, oleh sebab itu setiap tahun penerimaan pajak senantiasa diupayakan untuk terus meningkat. Ada tiga unsur yang menentukan penerimaan pajak, yakni undangundang perpajakan yang tepat, kepatuhan serta kesadaran dari Wajib Pajak dan aparat perpajakan yang cakap dan bersih.

Pemungutan pajak bukanlah perkara yang mudah, selain membutuhkan peran aktif petugas pajak, kemauan dan kesadaran dari wajib pajak itu sendiri sangat di perlukan. Dalam pemungutannya pajak Indonesia menganut system self assessment yang memberi kepercayaan kepada wajib pajak untuk menghitung, menyetor dan melapor sendiri pajaknya, menyebabkan kebenaran pembayaran pajak tergantung pada kejujuran wajib pajak sendiri dalam pelaporan kewajiban perpajakannya. Pada pelaporan pajak 2018, dalam upaya meningkatkan pelayanan perpajakan yang semakin mudah dalam pemenuhan kewajiban perpajakan kepada wajib pajak, DJP menerapkan system pelaporan dengan elektronik yang disebut dengan e-Filling.

e-filing adalah suatu cara penyampaian Surat Pemberitahuan (SPT) secara elektronik yang dilakukan secara sistem online dan real time melalui perusahaan penyedia jasa aplikasi yang ditunjuk oleh Dirjen Pajak. Dengan adanya sistem efilling ini akan membantu memangkas biaya dan waktu yang dibutuhkan wajib pajak untuk mempersiapkan, memproses, dan melaporkan SPT ke kantor pelayanan Pajak secara benar dan tepat waktu. Namun dalam praktiknya, sistem ini bukan merupakan hal yang mudah untuk diimplementasikan. Dikarenakan kurangnya pemahaman wajib pajak mengenai internet dan sistem pelaporan elektronik, serta keterbatasan jaringan internet di beberapa daerah.

Fasilitas $e$ - filling diharapkan dapat menyelesaikan masalah pada sektor administrasi perpajakan di Indonesia, serta menjadi jalan keluar yang dapat membantu memangkas biaya, sumber daya dan waktu yang dibutuhkan untuk mempersiapkan, memproses, dan melaporkan SPT ke Kantor Pelayanan Pajak (KPP) secara benar dan tepat waktu yang kemudian mendukung KPP dalam melakukan percepatan penerimaan laporan SPT dan perampingan kegiatan administrasi, pendataan, akurasi data, distribusi dan persiapan pelaporan SPT.

Kantor Pelayanan Pajak Pratama Mataram Timur merupakan salah satu kantor pelayanan pajak yang ada di Nusa Tenggara Barat yang wilayah kerjanya meliputi Kabupaten Lombok Barat dan Kabupaten Lombok Utara. Jumlah wajib pajak yang terdaftar di KPP Pratama Mataram Timur sebesar 21.260 WP yang tersebar 
Kabupaten Lombok Barat 5.202 dan 16.058 di Kabupaten Lombok Utara. (KPP Pratama Mataram Timur)

Berdasarkan latar belakang tersebut penulis tertarik untuk mengangkat judul "Efektivitas penyampaian SPT Tahunan Wajib Pajak Orang Pribadi melalui e-Filling terhadap target penerimaan SPT Tahunan Pada Kantor Pelayanan Pajak Pratama Mataram Timur"

\section{TUJUAN}

1. Mengetahui target dan realisasi Penyampaian SPT Tahunan dengan adanya $e-$ Filling pada Kantor Pajak Pratama Mataram Timur.

2. Mengetahui efektivitas penyampaian SPT Tahunan melalui e-Filling di Kantor Pelayanan Pajak Pratama Mataram Timur.

\section{TELAAH LITERATUR DAN PENGEMBANGAN HIPOTESIS Pengertian pajak}

Pengertian tentang pajak oleh beberapa ahli menjelaskan dengan formulasi yang berbeda-beda, namun pada prinsipnya menekankan pada subjek, objek pajak dan pemanfaatannya. Dalam UU No. 16 Tahun 2009 tentang Ketentuan Umum Dan Tata Cara Perpajakan pajak didefinisikan sebagai kontribusi wajib kepada negara yang terutang oleh orang pribadi atau badan yang bersifat memaksa berdasarkan Undang-Undang, dengan tidak mendapatkan imbalan secara langsung dan digunakan untuk keperluan negara bagi sebesar-besarnya kemakmuran rakyat. Adriani (2014), mendifinisikan bahwa: Pajak adalah iuran masyarakat pada negara (yang sifatnya dapat dipaksakan) yang terutang oleh yang wajib membayarnya menurut peraturan-peraturan, dengan tidak mendapat prestasi kembali yang dapat ditunjuk, dan yang gunanya adalah untuk membiayai pengeluaran-pengeluaran umum berhubung dengan tugas negara yang menyelenggarakan pemerintahan.Kemudian Soemitro (2007), mendifinisikan pajak sebagai iuran kepada kas negara berdasarkan undang-undang (yang dapat dipaksakan) dengan tidak mendapat jasa timbal (kontraprestasi) yang langsung dapat ditunjukkan dan yang digunakan untuk membayar pengeluaran umum. Sedangkan menurut Feldmann dalam Resmi (2011) pajak adalah prestasi yang dipaksakan sepihak oleh dan terutang kepada pengusaha (menurut norma-norma yang ditetapkannya secara umum), tanpa adanya kontraprestasi dan semata-mata digunakan untuk menutup pengeluaran-pengeluaran umum.

Dari pengertian-pengertian tersebut dapat disimpulkan bahwa ciri yang melekat pada pengertian pajak, adalah sebagai berikut:

1. Pajak merupakan kontribusi wajib warga Negara

2. Pajak dipungut berdasarkan Undang-Undang serta aturan pelaksanaannya yang bersifat dapat dipaksakan

3. Dalam pembayaran pajak tidak dapat ditunjukkan adanya kontraprestasi secara langsung 


\section{Pajak diperuntukkan untuk pengeluaran-pengeluaran Negara}

\section{Fungsi pajak}

1. Fungsi Penerimaan (Budgetair) yaitu pajak sebagai sumber dana bagi pemerintah untuk membiayai pengeluaran-pengeluarannya terutama atau semata-mata untuk memperoleh uang sebanyak-banyaknya baik yang besifat rutin maupun pembangunan untuk memasukan uang ke kas Negara atau sebagai sumber penerimaan Negara.

2. Fungsi Pengatur (Regulerend) yaitu pajak sebagai alat untuk mengatur atau melaksanakan kebijakan pemerintah dalam bidang sosial dan ekonomi serta sebagai usaha pemerintah untuk turut campur tangan dalam mengatur apabila perlu adanya perubahan susunan pendapatan dan kekayaan dalam sektor swasta.

\section{Hak dan Kewajiban Wajib Pajak}

1. Hak-Hak Wajib Pajak

Hak-hak wajib pajak menurut undang-undang No. 28 Tahun 2007 adalah sebagai berikut (Resmi;2013):

1) Melaporkan beberapa masa pajak dalam 1 (satu) Surat Pemberitahuan Masa.

2) Mengajukan surat keberatan dan banding bagi Wajib Pajak dengan kriteria tertentu.

3) Memperpanjang jangka waktu penyampaian Surat Pemberitahuan Tahunan Pajak Penghasilan untuk paling lama 2 (dua) bulan dengan cara menyampaikan pemberitahuan secara tertulis atau dengan cara lain kepada Direktur Jendaral Pajak.

4) Membetulkan Surat Pemberitahuan yang telah disampaikan dengan menyampaikan pernyataan tertulis, dengan syarat Direktur Pajak belum melakukan tindakan pemeriksaan.

5) Mengajukan permohonan pengembalian kelebihan pembayaran pajak.

6) Mengajukan keberatan kepada Direktur Jendral Pajak atas suatu:

a. Pajak surat ketetapan kurang bayar

b. Surat ketetapan pajak kurang bayar tambahan

c. Surat ketetapan pajak nihil

d. Surat ketetapan pajak lebih bayar

e. Pemotongan dan pemungutan pajak oleh pihak ketiga berdasarkan ketentuan peraturan perundang-undangan perpajakan.

7) Mengajukan permohonan banding kepada badan peradilan pajak atas surat keputusan keberatan.

8) Mengajukan keberatan kepada Direktur Jendral Pajak atas suatu:
a. Pajak surat ketetapan kurang bayar
b. Surat ketetapan pajak kurang bayar tambahan
c. Surat ketetapan pajak nihil 
d. Surat ketetapan pajak lebih bayar

e. Pemotongan dan pemungutan pajak oleh pihak ketiga berdasarkan ketentuan peraturan perundang-undangan perpajakan.

9) Mengajukan permohonan banding kepada badan peradilan pajak atau surat keputusan keberatan.

10) Menunjuk seorang kuasa dengan surat kuasa khusus untuk menjalankan hak dan memenuhi kewajiban sesuatu dengan ketentuan Peraturan PerundangUndangan perpajakan.

11) Memperoleh pengurangan atau penghapusan sanksi administrasi pajak berupa bunga atas keterlambatan pelunasan kekurangan pembayaran pajak dalam hal wajib pajak menyampaikan pembetulan surat pemberitahuan tahunan pajak penghasilan sebelum tahun pajak 2007, yang mengakibatkan pajak yang masih harus dibayar menjadi lebih besar dan dilakukan paling lama dalam jangka waktu 1 (satu) tahun setelah berlakunya UU No. 28 Tahun 2007.

2. Kewajiban Wajib Pajak

Kewajiban wajib pajak menurut undang nomor 28 tahun 2007 adalah sebagai berikut (Resmi;2013):

1. Mendaftarkan diri pada Kantor Direktorat Jendral Pajak yang wilayah kerjanya meliputi tempat tinggal atau tempat tinggal atau tempat kedudukan wajib pajak dan kepadanya diberikan Nomor Pokok Wajib Pajak, apabila telah memenuhi persyaratan subjektif dan objektif.

2. Melaporkan usahanya pada kantor Direktorat Jendral Pajak yang wilayah kerjanya tempat tinggal atau tempat kedudukan pengusaha dan tempat kegiatan usaha dilakukan untuk dikukuhkan menjadi pengusaha kena pajak.

3. Mengisi surat pemberitahuan dengan benar, lengkap, dan jelas, dalam bahasa Indonesia dengan menggunakan huruf latin, angka arab, satuan mata uang rupiah, serta menandatangani dan menyampaikannya ke Kantor Direktorat Jendral Pajak tempat wajib pajak terdaftar atau dikukuhkan atau tempat lain yang ditetapkan oleh Direktorat Jendral Pajak.

4. Menyampaikan surat pemberitahuan dalam bahasa Indonesia dengan menggunakan satuan mata uang rupiah yang diizinkan, yang pelaksanaanya diatur dengan atau berdasarkan Peraturan Menteri Keuangan.

5. Membayar atau menyetor pajak yang terutang dengan menggunakan surat setoran pajak ke kas Negara melalui tempat pembayaran yang diatur dengan berdasarkan Peraturan Menteri Keuangan.

6. Membayar pajak yang terutang sesuai dengan perundang-undangan perpajakan, dengan tidak menggantungkan pada adanya surat ketetapan pajak.

7. Menyelenggarakan pembukuan bagi wajib pajak orang pribadi yang melakukan kegiatan usaha atau pekerjaan bebas atau wajib badan, dan melakukan pencatatan bagi wajib pajak orang pribadi yang melakukan kegiatan usaha atau pekerjaan bebas. 


\section{Membantu pelaksanaan pemeriksaan}

a. Memperlihatkan dan/atau meminjamkan buku atau catatan, dokumen yang menjadi dasarnya, dan dokumen lain yang berhubungan dengan penghasilan yang diperoleh, kegitan usaha, pekerjaan bebas wajib pajak, atau objek yang terutang pajak.

b. Memberikan kesempatan untuk memasuki tempat atau ruang yang dipandang perlu dan memberi bantuan guan kelancaran pemeriksaan.

c. Memberikan keterangan lain yang diperlukan apabila diperiksa.

\section{Sistem Pemungutan Pajak}

a. Official Assesment System

Sistem pemungutan pajak yang memberikan kewenangan aparatur perpajakan untuk menentukan sendiri jumlah pajak yang terutang setiap tahunya sesuai dengan peraturan perundang-undangan perpajakan yang berlaku.Dalam sistem aini, inisiatif serta kegiatan menghitung dan memungut pajak sepenuhnya berada ditangan para aparatur perpajakan.Dengan demikian, behasil atau tidaknya pelaksanaan pemungutan pajak banyak tergantung pada aparatur perpajakan (peranan dominan ada pada aparatur perpajakan).

\section{b. Self Assesment System}

System pemungutan pajak yang memberi wewenang Wajib Pajak dalam menentukan jumlah sendiri pajak yang terutang setiap tahunnya sesuai dengan peraturan perundang-undangan perpajakan yang berlaku. Dalam system ini, inisiatif serta kegiatan menghitung dan memungut pajak sepenuhnya berada ditangan Wajib Pajak. Wajib Pajak dianggap mampu menghitung pajak, mampu memahami undang-undang perpajakan yang sedang berlaku, dan mempunyai kejujuran yang tinggi, serta menyadari akan arti pentingnya membayar pajak. Oleh karena itu, wajib pajak diberikan kepercayaan untuk, menghitung sendiri, membayar sendiri, melaporkan sendiri serta mempertanggungjawabkan pajak yang terutang.

\section{c. Withholding System}

System pemungutan pajak yang member wewenang kepada pihak ketiga yang ditunjuk untuk menentukan besarnya pajak yang terutang oleh Wajib Pajak sesuai dengan peraturan perundang-undangan perpajakan yang berlaku.Penunjukkan pihak ketiga ini dilakukan sesuai dengan peraturan perundang-undangan perpajakan, kepeutusan presiden, dan peraturan lainya untuk memotong dan memungut pajak, menyetor, dan mempertanggungjawabkan melalui sarana perpajakan yang tersedia.Berhasil atau tidaknya pelaksanaan pemungutan pajak banyak tergantung pada pihak ketiga yang ditunjuk.

\section{Surat Pemberitahuan (SPT)}


Surat Pemberitahuan dalam Undang-Undang Nomor 28 Tahun 2007 pasal 1 ayat (11) adalah :"Surat Pemberitahuan adalah surat yang oleh Wajib Pajak digunakan untuk melaporkan penghitungan dan/atau pembayaran pajak, objek pajak dan/atau bukan objek pajak, dan/atau harta dan kewajiban sesuai dengan ketentuan peraturan perundangundangan perpajakan."

Surat Pemberitahuan (SPT) memiliki fungsi berdasarkan jenis pajaknya, yaitu:

1) Wajib Pajak untuk Pajak Penghasilan (PPh)

Fungsi Surat Pemberitahuan bagi Wajib Pajak Pajak Penghasilan (PPh) (Mardiasmo, 2016) adalah sebagai sarana dalam mempertanggungjawabkan dan melaporkan tentang:

a. Perhitungan pajak terutang sesuai keadaan sebenarnya

b. Pelunasan atau pembayaran pajak yang telah dilaksanakan sendiri oleh wajib pajak dan/atau melalui pemungutan atau pemotong pihak lain dalam 1 Tahun Pajak atau Bagian Tahun Pajak

c. Penghasilan yang merupakan objek pajak dan/atau bukan objek pajak

d. Harta dan kewajiban berupa hutang atau tanggungan wajib pajak

e. Pembayaran dari pemungutan/pemotongan tentang pemungutan/pemotongan pajak orang pribadi atau badan lain dalam satu Masa Pajak sesuai dengan ketentuan peraturan perundang-undangan perpajakan.

2) Pengusaha Kena Pajak (PKP)

Fungsi Surat Pemberitahuan bagi PKP (Mardiasmo, 2016) adalah sebagai sarana untuk mempertanggungjawabkan dan

melaporkan tentang:

1. Perhitungan Pajak Pertambahan Nilai (PPN) dan Pajak Penjualan Atas Barang Mewah (PPnBM) yang sebenarnya terutang

2. Pengkreditan Pajak Masukan terhadap Pajak Keluaran

3. Pembayaran atau pelunasan pajak yang telah dilaksanakan sendiri oleh PKP dan/atau melalui pihak lain dalam satu Masa Pajak sesuai dengan peraturan perundang-undangan yang berlaku.

3) Pemotong atau Pemungut Pajak

Fungsi Surat Pemberitahuan bagi pemotong/pemungut pajak (Mardiasmo, 2016) adalah sebagai sarana untuk mempertanggungjawabkan dan melaporkan pajak yang dipotong/dipungut dan disetorkannya.

Dalam Surat Edaran Direktur Jenderal Pajak Nomor SE01/PJ/2016 tentang petunjuk teknis tata cara penerimaan dan pengolahan Surat Pemberitahuan Tahunan, pengertian SPT Tahunan adalah "Surat Pemberitahuan Tahunan yang selanjutnya disebut SPT Tahunan adalah Surat Pemberitahuan untuk suatu tahun pajak atau bagian tahun pajak, yang meliputi SPT Tahunan Pajak Penghasilan Wajib Pajak Orang Pribadi (SPT 1770, SPT 1770 S, SPT 1770 SS), SPT Tahunan Pajak Penghasilan Wajib Pajak Badan (SPT 1771 dan SPT 1771/\$), termasuk SPT Tahunan Pembetulan."

Batas Waktu Penyampaian Surat Pemberitahuan 
Menurut Mardiasmo (2016) batas waktu penyampaian SuratPemberitahuan yaitu :

1. Surat Pemberitahuan Masa, paling lama 20 hari setelah akhir Masa Pajak. Khusus Surat Pemberitahuan Masa Pertambahan Nilai (PPN) batas waktu penyampaian paling lama akhir bulan berikutnya setelah berakhirnya Masa Pajak.

2. Surat Pemberitahuan Tahunan Pajak Penghasilan (PPh) Wajib Pajak orang pribadi, paling lama 3 bulan setelah akhir Tahun Pajak

3. Surat Pemberitahuan Tahunan Pajak Penghasilan (PPh) Wajib Pajak badan, paling lama 4 bulan setelah akhir Tahun Pajak.

\section{E-Filing}

e-Filing adalah sebuah layanan pengiriman atau penyampaian Surat Pemberitahuan Pajak (SPT) secara elektronik baik untuk Orang Pribadi (OP) maupun Badan ke Direktorat Jenderal Pajak (DJP) menggunakan jaringan internet melalui ASP (Application Service Provider) atau Penyedia Jasa Aplikasi lainnya, sehingga WP tidak perlu lagi melakukan pencetakan semua formulir laporan.Penyampaian SPT melalui pelayanan e-filing atau e-SPT pertama kali diatur dengan keputusan dirjen pajak melalui KEP- 05/PJ./2005 tentang tata cara penyampaian Surat Pemberitahuan secara elektronik (e-filing) melalui Perusahaan Penyedia Jasa Aplikasi (ASP). Adapun beberapa Perusahaan Penyedia Jasa Aplikasi (ASP). Selain 2 (dua) jenis SPT Tahunan WP OP 1770 S dan 1770 S, untuk jenis SPT lainnya dilaporkan melalui Penyedia Jasa Aplikasi (Application Service Provider-ASP) yang telah ditunjuk oleh Dirketorat Jenderal Pajak

Dalam Peraturan Direktorat Jenderal Pajak Nomor PER1/PJ/2014 tentang tata cara penyampaian SPT Tahunan bagi Wajib Pajak Orang Pribadi yang menggunakan formulir 1770 S atau 1770 SS secara e-filing melalui website Direktorat Jenderal Pajak "e-Filing adalah suatu cara penyampaian SPT Tahunan secara elektronik yang dilakukan secara online dan real time melalui internetpada website Direktorat Jenderal Pajak (www.pajak.go.id) atau Penyedia Jasa Aplikasi atau Application Service Provider (ASP)."

1. Motivasi Penyampaian Melalui E-Filing

Penyampaian SPT melalui e-Filling adalah dalam rangka menyesuaikan perkembangan teknologi informasi serta meningkatkan pelayanan kepada Wajib Pajak. Maka Direktorat Jenderal Pajak memberi kemudahan kepada wajib pajak dalam penyampaian Surat Pemberitahuan Tahunan khususnya bagi wajib pajak Orang Pribadi (OP) yang menggunakan formulir 1770 S dan 1770 SS yaitu melalui e-Filing melalui website Direktorat Jenderal Pajak (DJP) yaitu www.pajak.go.id

2. Dasar Hukum E-Filing

a. PMK - 181/PMK.03/2007 tentang Bentuk dan Isi SPT, Serta Tata Cara Pengambilan, Pengisian, Penandatanganan, dan Penyampaian SPT stdd PMK152/PMK.03/2009. 
b. PER-1/PJ/2014 tanggal 6 Januari 2014 tentang Tata Cara Penyampaian SPT Tahunan bagi wajib pajak Orang Pribadi (OP) yang menggunakan formulir $1770 S$ dan 1770 SS yaitu melalui e-Filing melalui website Direktorat Jenderal Pajak (DJP).

Pengisian dan Pelaporan SPT Tahunan secara elektronik melalui e-filing yang diatur dalam Peraturan Direktorat Jenderal Pajak Nomor PER-1/PJ/2014 untuk saat ini melayani dua jenis SPT Tahunan, yaitu:

1. SPT Tahunan PPh Orang Pribadi Formulir 1770 Sederhana (1770S) Formulir $1770 \mathrm{~S}$ digunakan bagi Wajib Pajak Orang Pribadi yang sumber penghasilannya diperoleh dari satu/lebih pemberi kerja dan memiliki penghasilan lain yang bukan dari kegiatan usaha dan/atau pekerja bebas.

2. SPT Tahunan PPh Wajib Pajak Orang Pribadi Formulir 1770 Sangat Sederhana (1770SS) Formulir 1770SS digunakan oleh Wajib Pajak Orang Pribadi yang mempunyai penghasilan hanya dari satu pemberi kerja selain dari usaha dan/atau pekerjaan bebas dengan jumlah penghasilan bruto tidak lebih dari Rp 60.000.000,00 setahun.

3. SPT Tahunan PPh Badan Formulir 1771 Formulir 1771 digunakan bagi Wajib Pajak Badan (PT, CV, perseroan lainnya, BUMN/D, koperasi, yayasan), Wajib Pajak Orang Pribadi Luar Negeri yang berstatus BUT, Wajib Pajak Badan yang hanya memperoleh penghasilan yang telah dikenakan PPh Final, dan Wajib Pajak Kontrak Investasi Kolektif (KIK).

4. SPT Tahunan PPh Orang Pribadi Formulir 1770 dan 1770 S Formulir 1770 digunakan bagi Wajib Pajak Orang Pribadi yang mempunyai penghasilan dari kegiatan usaha dan/atau pekerja bebas.

5. SPT Masa PPh Pasal 21/26

6. SPT Masa PPh Pasal 4(2)

7. SPT Masa PPN dan PPnBM

Efektivitas e-Filling

Efektivitas adalah pencapaian tujuan secara tepat atau memilih tujuan-tujuan yang tepat dari serangkaian alternative atau pilihan cara dan menentukan pilihan dari beberapa pilihan lainnya. Efektivitas bias juga diartikan sebagai pengukuran keberhasilan dalam pencapaian tujuan-tujuan yang telah ditentukan. Menurut Kamus Besar Bahasa Indonesia, efektivitas berasal dari kata efektif yang mempunyai arti efek, pengaruh, akibat atau dapat membawa hasil. Jadi efektivitas adalah keaktifan, daya guna, adanya kesesuaian dalam suatu kegiatan untuk melaksanakan tugas dengan sasaran yang dituju. Efektivitas pada dasarnya menunjukkan pada taraf tercapainya hasil. Berdasarkan uraian di atas dapat disimpulkan bahwa efektifitas adalah suatu keadaan yang menunjukkan sejauh mana rencana dapat tercapai. Semakin banyak rencana yang dapat dicapai, semakin efektif pula kegiatan tersebut, sehingga kata efektivitas dapat juga diartikan sebagai tingkat keberhasilan yang dapat dicapai dari suatu cara atau usaha tertentu sesuai dengan tujuan yang hendak di capai. 
Untuk mengukur efektivitas sesuai dengan pengertian efektivitas di atas maka efektivitas di ukur dengan cara membandingkan antara jumlah WP yang di targetkan untuk menyampaikan SPT melalui e-Filling dengan realisasi penyampaian SPT melalui e-Filling. Semakin tinggi rasio antara realisasi dengan target maka semakin tinggi efektivitasnya.

Rumus perhitungan efektivitas menurut Halim (2004:135)

\begin{tabular}{c}
\hline Efektivitas $=$ Realisasi Penerimaan SPT Tahunan \\
Target Pajak
\end{tabular}

Guna mengetahui efektif atau tidaknya penerimaan SPT Tahunan pada KPP Pratama Mataram Timur (tempat PKL penulis), dapat diukur dengan menggunakan kriteria dan indikator dibawah ini:

Tabel 1. Kriteria efektivitas penerimaan SPT Tahunan

\begin{tabular}{|c|c|c|}
\hline No & Capaian & Kriteria \\
\hline 1 & $>100 \%$ & Sangat efektif \\
\hline 2 & $90-100 \%$ & Efektif \\
\hline 3 & $80-90 \%$ & Cukup efektif \\
\hline 4 & $60-80 \%$ & Kurang efektif \\
\hline 5 & $<60 \%$ & Tidak efektif \\
\hline
\end{tabular}

Sumber: Depdagri, Kepmendagri No.690.900.329 (Hasannudin, 2013)

\section{PENGUMPULAN DAN ALAT ANALISIS DATA}

Data yang digunakan dalam penulisan artikel ini adalah data sekunder yang bersumber dari Kantor Pelayanan Pajak Pratama Mataram Timur berupa data target dan realisasi penerimaan pajak, jumlah SPT tahunan yang disampaikan oleh WP yang ada di Wilayah KPP Pratama Mataram Timur. Data yang sudah dikumpulkan dihitung dengan prosedur sebagai berikut:

1. Untuk mengetahui capaian antara target dan realisasi penerimaan pajak di KPP Pratama Mataram Timur digunakan rumus (KPP Pratama Mataram Timur):

Realisasi penerimaan pjk

Capaian $=$ $\times 100$

Target Penerimaan pjk

Dengan kreterian :

Sangat Baik ; Capaian > 90\%

Baik : Capaian 66-89\%

Cukup Baik : Capaian $55-65 \%$

Kurang Baik: Capaian < 55\% 
2. Untuk Mengatahui efektifitas penerimaan/penyampaian SPTn di gunakan rumus dari Halim (2004):

\begin{tabular}{|c|c|}
\hline Efektivitas = & Realisasi Penerimaan SPT Tahunan \\
\hline & Target Pajak \\
\hline
\end{tabular}

Kreteria yang digunakan seperti yang ditunjukkan pada tabel 2,1

\section{HASIL DAN PEMBAHASAN}

\section{Target dan Realisasi Penerimaan SPT Tahunan dengan Adanya e-Filling pada KPP Pratama MataramTimur.}

Target dan realisasi penerimaan SPT Tahunan dengan adanya e-Filling seperti terlihat pada tabel berikut.

Tabel 2. Target dan realisasi penerimaan SPT Tahunan melalui e-Filling tahun 2017-2019

\begin{tabular}{|c|c|c|c|}
\hline Tahun & Target & Realisasi & Capaian \\
\hline 2017 & 4.195 & 4.777 & $113,87 \%$ \\
\hline 2018 & 6.310 & 6.285 & $99.60 \%$ \\
\hline 2019 & 7.926 & 8.330 & $105,10 \%$ \\
\hline
\end{tabular}

Sumber: KPP Pratama Mataram Timur.

Berdasarkan tabel 4.1. dapat dijelaskan bahwa secara umum target dan realisasi penerimaan SPT Tahunan terus meningkat dalam 3 tahun terkhir namun capaianya menunjukkan ada penurunan dari tahun 2017 ke 2018 yaitu dari 113,87 menjadi 99,60\% sedangkan tahun 2018 ke 2019 capaiannya meningkat menjadi $105,10 \%$. Penurunan capaian dari 113,87\% menjadi 99,60\% disebabkan karena pengaruh bencana alam gempa bumi yang terjadi pada bulan Agustus sampai dengan Desember 2018 yang menyebabkan WP tidak bisa menyampaikan SPT tahunannya.

\section{Efektivitas penyampaian SPT Tahunan WP OP melalui e-Filling di Kantor Pelayanan Pajak Pratama Mataram Timur.}

Mekanisme penyampaian SPT melalui elektronik merupakan program kerja sekaligus indikator kinerja bagi DJP khususnya KPP Pratama Mataram Timur.Oleh karena itu dalam bagian berikut akan di jelaskan tentang efektivitas penyampaian SPT melalui elektronik. Untuk mengetahui efektivitas penyampaian SPT Tahunan melalui e-Filling dengan cara

1. merasiokan antara realisasi dengan target

2. menentukan kriteria efektivitas penerimaan SPT

3. menyimpulkan. 
Jumlah WP OP yang terdaftar di KPP Pratama Mataram timur 3 tahun terakhir seperti di tunjukkan pada tabel berikut:

Tabel 3. Jumlah WP OP pada KPP Pratama Mataram Timur.

\begin{tabular}{|c|l|c|c|c|}
\hline No & Wajib Pajak & $\mathbf{2 0 1 7}$ & $\mathbf{2 0 1 8}$ & $\mathbf{2 0 1 9}$ \\
\hline 1 & Pegawai Negeri & 1.327 & 1.787 & 2.041 \\
\hline 2 & Pegawai Swasta & 1.681 & 2.686 & 3.523 \\
\hline 3 & Pegawai BUMN/BUMD & 1.186 & 1.837 & 2.361 \\
\hline & JUMLAH & 4.195 & 6.310 & 7.926 \\
\hline
\end{tabular}

Sumber: KPP Pratama Mataram Timur 2019.

Dari tabel tersebut diketahui bahwa jumlah WP secara keseluruhan dari tahun ketahun terus meningkat, tahun 2017 sejumlah 4.195 dan tahun 2019meningkat menjadi 7.926 Wajib Pajak. Jumlah WP tersebut untuk tahun pajak 2018 sampai dengan tahun 2019 di haruskan menyampaikan SPT melalui e-Filling dengan harapan terjadi efektivitas penyampaian SPT tersebut.

Berdasarkan data yang di peroleh di KPP Pratama Mataram Timur jumlah WP yang di targetkan dan di realisasikan serta perhitungan efektivitasnya untuk 3 tahun terakhir di sajikan pada tabel 4.3 berikut:

Tabel 4. Efektivitas dan kriteria penyampaian SPT Tahun 2017-2019.

\begin{tabular}{|c|c|c|c|l|}
\hline Tahun & Target & Realisasi & Efektivitas & Kriteria \\
\hline 2017 & 4.195 & 4.777 & $113,88 \%$ & Sangat Efektif \\
\hline 2018 & 6.310 & 6.285 & $99.60 \%$ & Efektif \\
\hline 2019 & 7.926 & 8.330 & $105,10 \%$ & Sangat Efektif \\
\hline
\end{tabular}

Sumber: KPP Pratama mataram timur2019

Dari data di atas memperlihatkan bahwa efektivitas penyampaian SPT Tahunan WP OP melalui e-Filling pada tahun 2017 dinyatakan sangat efektif dengan angka sebesar 4.777 dari target sebesar 4.195, sehingga persentase penerimaan SPT Tahunan WP OP tahun 2017 adalah sebesar 113,88 \%.

Pada tahun 2018 penyampaian SPT Tahunan melalui e-Filling sebesar 99.60\%, hal tersebut menunjukkan bahwa penyampaian SPT Tahunan WP OP melalui e-Filling pad;'a tahun 2018 adalah efektif. Namun pada tahun 2019 penyampaian SPT Tahunan WP OP melalui e-Filling mengalami peningkatan menjadi $105.10 \%$ atau termasuk dalam kriteria sangat efektif.

\section{SIMPULAN}

1. Secara umum target dan realisasi penerimaan SPT Tahunan terus meningkat dalam 3 tahun terkhir namun capaianya menunjukkan ada penurunan dari tahun 2017 ke 2018 yaitu dari 113,87 menjadi 99,60\% sedangkan tahun 2018 ke 2019 
capaiannya meningkat menjadi $105,10 \%$. Penurunan capaian dari $113,87 \%$ menjadi 99,60\% disebabkan karena pengaruh bencana alam gempa bumi yang terjadi pada bulan Agustus sampai dengan Desember 2018 yang menyebabkan WP tidak bisa menyampaikan SPT tahunannya.

2. Efektivitas penyampaian SPT Tahunan melalui e-Filling di Kantor Pelayanan Pajak Pratama Mataram Timurpada tahun 2017 dinyatakan sangat efektif dengan angka sebesar 4.777 dari target sebesar 4.195 , sehingga persentase penerimaan SPT Tahunan WP OP tahun 2017 adalah sebesar 113,88 \% , Pada tahun 2018 penyampaian SPT Tahunan melalui e-Filling sebesar 99.60\%, hal tersebut menunjukkan bahwa penyampaian SPT Tahunan WP OP melalui eFilling pada tahun 2018 adalah efektif. Namun pada tahun 2019 penyampaian SPT Tahunan WP OP melalui e-Filling mengalami peningkatan menjadi $105.10 \%$ atau termasuk dalam kriteria sangat efektif.

\section{DAFTAR PUSTAKA}

Anonim, 2017/2018, Buku Pedoman Praktek Kerja Lapangan (PKL), Program Studi D III Perpajakan Fakultas Ekonomi dan Bisnis, Universitas Mataram.

Anonim, 2011. "Buku Panduan Hak dan Kewajiban Wajib Pajak". Jakarta: Direktorat Jenderal Pajak

Anonim, 2018. "Undang-Undang Nomor 28 Tahun 2007 Tentang Perubahan Ketiga atas Undang-Undang Nomor 6 Tahun 1983 Tentang Ketentuan dan Tata Cara Perpajakan",

Hasannudin, 2014. Analisis Efektivitas dan Kontribusi Pajak Kendaraan Bermotor Terhadap Penerimaan Pendapatan Asli Daerah di Provinsi Maluku Utara.

Halim, Abdul. 2004. Akuntansi Keuangan Daerah Edisi Revisi. Salemba Empat, Jakarta.

Waluyo. 2011. Perpajakan Internasional. Jakarta; Salemba Empat, Buku I

Resmi, Siti. 2013. Perpajakan: Teori dan Kasus. Jakarta: Salemba Empat, Buku I.

2013. Perpajakan: Teori dan Kasus. Jakarta; Salemba Empat,

Buku II

Mardiasmo. 2009. Perpajakan. Yogyakarta; ANDI.

Anonim, 2018. Cara Melaporkan SPT Ttahunan Onlinedengane-filing, https://tirto.id/ 